substance, as was reported previously, both in $n$-butanol/acetic acid/water $(4: 1: 2)$ and in 80 per cent phenol.

This substance, after recrystallization from hot water, contained $2.5 \mathrm{~mol}$. of water of crystallization and melted, effervescing at $174^{\circ} \mathrm{C}$., and produced dark green dyes and red orange dyes with ferric chloride and with benzidine diazo reagents ${ }^{6}$, respectively.

When hydrolyzed with 10 per cent potassium hydroxide, the substance gave phloroglucinol and protocatechuic acid and it dissolved in a sodium bicarbonate solution evolving carbon dioxide, suggesting the presence of a carboxylic group in its molecule. These facts suggest that this substance is identical with a protocatechuoyl phloroglucinol carboxylic acid (anal.: calc. for $\mathrm{C}_{14} \mathrm{H}_{10} \mathrm{O}_{8} \cdot 2 \cdot 5 \mathrm{H}_{2} \mathrm{O}$ : C, 47.87 ; H, $4 \cdot 30$; found : C, 48.44; H, 4.39).

Since this substance easily loses the carboxyl group on heating to $100^{\circ} \mathrm{C}$., it was methylated with an excess of diazomethane and the methyl ether methyl ester was obtained as colourless needles, which melted at $144^{\circ} \mathrm{C}$. after recrystallization from absolute alcohol (anal : found : C, 60.91; H. 5.16). When admixed with 2 -veratroyl 4, 6 -dimethoxyphloroglucinol carboxylic acid methyl ester (anal. : calc. for $\mathrm{C}_{19} \mathrm{H}_{20} \mathrm{O}_{8}$ : C, 60, 63 ; $\mathrm{H}, 5 \cdot 36$; found: C, $60 \cdot 69$; $\mathrm{H}, 5 \cdot 02$ ), which had been synthesized from 2, 4-dimethoxyphloroglucinol carboxylic acid methyl ester and veratroyl chloride, this methyl ether methyl ester did not show any depression of melting point, suggesting the identity of these substances.

From these results it is evident that the substance produced by the fungus is identical with 2-protocatechuoyl phloroglucinol carboxylic acid.

We are grateful to Mr. M. Yoneyama, Biological Laboratory, University of Hiroshima, for identifying the fungus and to Dr. M. Hasegawa, Government Forest Experiment Station, for his helpful advice.

S. HATTORI

I. NOGUCHI

Botanical Institute,

University of Tokyo, Tokyo.

July 9.

${ }^{1}$ Murray, C. W., Booth, A. N., DeEds, F., and Jones, F. T., J. Amer. 2 Pharm. Ass., Sci., E., 43, 361 (1954). Chem., 223, 251 (1956).

2 Carl D. Douglas and Rose Hogan, $J$. Biol. Chem., 230, 625 (1958)

: Hattori, S., and Noguchi, I., Bot. Mag. (Tokyo), 71, 43 (1958).

- Yoneyama, M., Bot. Mag. (Tokyo), 72, 91 (1959).

\section{Chemical Nature of a Plant-Virus Inhibitor from Rice}

THE inhibition of tobacco mosaic virus infection of primary bean leaves (Phaseolus vulgaris $\mathrm{L}$. var. Pinto) by extracts of various portions of rice plants has been described recently ${ }^{1}$. The inhibitor or inhibitors present in rice resemble those derived from other plants such as spinach (Spinacea oleracea L.) ${ }^{2}$, poke weed (Phytolacca acinosa Roxb. var. esculenta) ${ }^{3}$, New Zealand spinach (Tetragonia expansa Murr. ${ }^{4}$, and sweet william (Dianthus barbatus L.) ${ }^{5}$, in that the infection of test plants is inhibited when the plant extract and virus inoculum are mixed and applied simultaneously. The inhibitor in rice extracts differs in that it protects bean leaves against tobacco mosaic virus infection even when applied to the leaves (which are then rinsed with water) 1-3 days prior to inoculum application. In so far as we are aware, the only other plant extracts that protected test plants against virus infection were derived from carnation (Dianthus caryophyllus L.) ${ }^{6}$, but the time between inhibitor application and inoculation was only 1-3 hr.

Experiments were conducted to determine the general chemical nature of the inhibitor as a basis for subsequent more detailed chemical investigation. The source of the inhibitor used was rice polish, since the inhibitor is concentrated in this readily available by-product in the milling of rice. The antiviral activity of the various chemical fractions of rice polish was determined by the local-lesion bioassay described by Holmes?. In these assays one member of each pair of opposite primary bean leaves was rubbed with the preparation plus tobacco mosaic virus and the opposite member with a comparable untreated control inoculum.

The inhibitor could be extracted from the polish with water, but not with methanol, and addition of methanol to the water extract caused complete inactivation with the formation of a precipitate. Centrifugation of the cloudy aqueous extract at 15,000 r.p.m. for $30 \mathrm{~min}$. gave a clear, slightly yellow solution retaining all its activity. Addition of 20 per cent trichloroacetic acid to a final acid concentration of 10 per cent in the extract completely destroyed the activity of the inhibitor, with the formation of a slight precipitate. Addition of cold saturated ammonium sulphate solution to cold rice-polish extract to 80 per cent saturation, followed by centrifugation, gave a precipitate that was found to be active. Very slow addition of cold absolute ethanol to cold ricepolish extract, to give a final ethanol concentration of 40 per cent, followed by centrifugation, gave an active precipitate. By mixing the aqueous extract with various powdered adsorbents, it was found that the inhibitor was adsorbed on alumina, magnesium oxide ('Sea Sorb'), and charcoal, but not on silica ('Celite'). The inhibitor failed to pass through a Visking membrane in $4 \mathrm{hr}$. after the extract was placed in a stainless steel ultrafiltration apparatus and $40 \mathrm{lb}$. of nitrogen per square inch was applied.

These preliminary experiments indicate that the virus inhibitor in rice polish is probably a protein, with a molecular weight greater than 13,000.

The aqueous extract of rice polish loses its activity slowly upon standing, even at $5-7^{\circ} \mathrm{C}$., with the formation of a precipitate which may be denatured protein. The fresh extract is approximately neutral in reaction, but on standing, either in the cold or at room temperature, it becomes acidic, with consequent loss in activity.

Further investigation of this virus inhibitor is in progress.

$$
\text { W. A. Jones M. JaCoBson }
$$

Entomology Research Division, Agricultural Research Service, U.S. Department of Agriculture, Beltsville, Maryland.

Plant Quarantine Division, Agriculture Research Service, U.S. Department of Agriculture, Glenn Dale, Maryland.

1 Allen, jun., T. C., and Kahn, R. P., Phytopath (Abst.) ,47, 515 (1957). 2 Kuntz, J. E., and Walker, J. C., Phytopath., 37, 561 (1947). Kassanis, B., and Kleczkowski, A., J. Gen. Microbiol., 2, 143 (1948). Benda, G. T. A., Virology, 2, 438 (1956).

seintraub, M., and Gilpatrick, J. D., Canad. J. Bot., 30, 549 (1952). ${ }^{s}$ Ragetli, H. W. J., Tijdschr. Planteziekten, 63, 245 (1957).

Holmes, F. C., Bot. Gaz., 87, 56 (1929). 